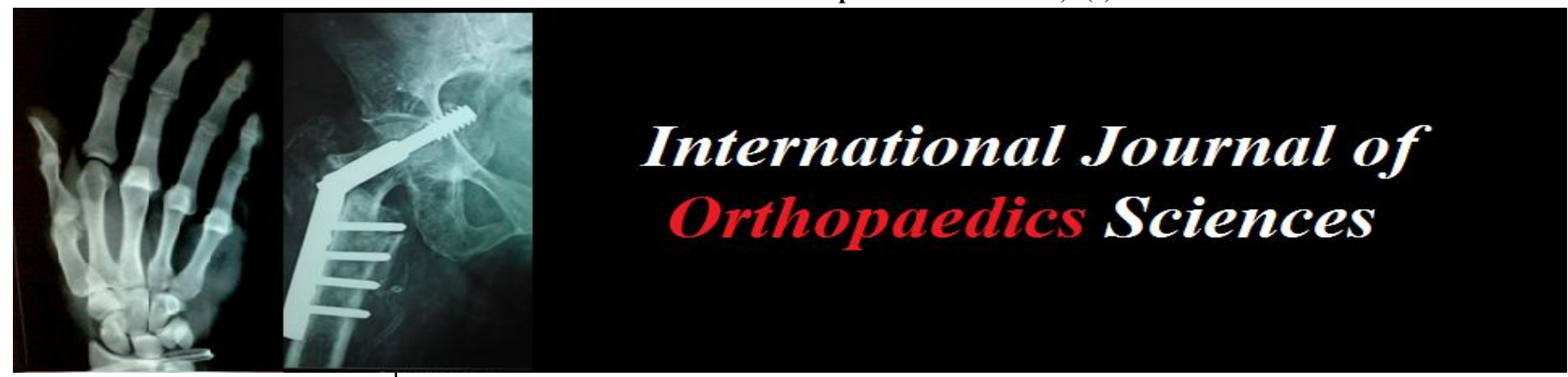

ISSN: $2395-1958$

IJOS 2019; 5(3): 180-184

(C) 2019 IJOS

www.orthopaper.com

Received: 06-05-2019

Accepted: 10-06-2019

Dr. Hardik R Patel

Zydush Medical Collage and

Hospital, Dahod, Gujarat, India
Correspondence

Dr. Hardik R Patel

Zydush Medical Collage and

Hospital, Dahod, Gujarat, India

\section{Study of patients treated for congenital dislocation of the knee with V-Y quadricepsplasty and capsulotomy and $\mathrm{K}$ wiring}

\section{Dr. Hardik R Patel}

\section{DOI: https://doi.org/10.22271/ortho.2019.v5.i3d.1528}

\section{Abstract}

Background: Congenital dislocation of the knee is a rare congenital anomaly. We were fortunate to have significant number of this patients. This study was undertaken to evaluate the result of surgical management of congenital dislocation of the knee.

Method: In this study total 12 patients (19 knees) were included. We compare this study with BELL, Atkins \& Sharrard series on the basis of age, sex, pattern of involvement, birth order, birth presentation, associate deformity and syndrome, range of movement. Our average follow up was 3 year and 8 months. Result: In this study 15 knees (78.95\%) had good result and 4 knees had fair result $(21.05 \%)$. In our series all 12 patients had ability to walk among which 8 patients were community walker and 4 patients were household walker. In our study only 1 patient (1 knee) had wound gaping (5.26\%).

Conclusion: Most of the patients presented at late stage requiring higher chances of surgery. If patients are referred at early age, there is possibility of treatment with plaster and decreasing need of surgery. Patients of idiopathic knee had good result then syndromic knee.

Keywords: congenital dislocation of the knee (CDK), Arthrogryposis multiplex congenital (AMC)

\section{Introduction}

Congenital dislocation of the knee is a rare congenital anomaly. It varies from simple hyperextension of the knee to complete dislocation of the tibia on the femur. Simple hyperextension is treated by cast and splint while complete dislocation is difficult to treat and requires complex surgery. Even after surgery knee does not become completely normal.

The exact etiology remains unknown. IT has been associated with certain factors including abnormal foetal position, Primary contracture of the quadriceps muscles, traumatic dislocation during parturition, Absence or hypoplasia of the cruciate ligaments, Lack of intrauterine space, Lack of amniotic fluid. Congenital dislocation of the knee is commonly associated with disorders like Arthrogryposis multiplex congenita, Larsen's syndrome, Down's syndrome etc. This study was undertaken to evaluate the result of surgical management of congenital dislocation of the knee.

Congenital dislocation of the knee is obvious deformity at the time of birth with hyperextension of the knee. Dimple or deep crease may be present over the anterior aspect of the knee. The patella is difficult to palpate. Congenital dislocation of the knee is usually associated with DDH $(45 \%)$ and foot deformity $(31 \%)^{[10]}$. Surgery is reserved for cases of failed conservative treatment or cases who present late, say after one year of age and options include VY Quadriceplasty, capsulotomy and $\mathrm{k}$ wiring. Bracing is used as adjunct to maintain reduction. We aim to review long term result after surgery at our institution.

\section{Materials and Method}

Our study was performed from April 2013 to April 2019 at the department of orthopaedics civil hospital and ZMCH Dahod. The average follow up period was $3 \mathrm{yr}$ and 8 month. There were 12 patients ( 19 knees) in which 8 male and 4 female patients. IN 8 patients 5 bilateral knee and 3 single. IN 4 female patients 2 bilateral and 2 single knee. 6 patients had AMC and 6 had idiopathic CDK. 
Birth history, birth presentation, family history, types of previous treatement, associate anomaly and ROM of the knee included. X ray and photographs of all the patients were taken at the time of admission, during surgery and during follow up. These were used to classify the deformity and to see how much improvement in patients. We classify the CDK using Leveuf and pais (1947) ${ }^{[1]}$ Classification. Describe congenital dislocation of the knee into three types.

In Grade I or congenital hyperextension of the knee: Knee flexion is easily possible and reduction is achieved with gentle stretching of the quadriceps. In Grade II or congenital subluxation of the knee: Knee flexion is not possible beyond neutral but the femoral and the tibial epiphyses are in contact and do not subluxate when flexion is attempted. In Grade III or true irreducible congenital dislocation of the knee: Knee flexion is not possible and the tibia which is anteriorly translated in the resting position may displace laterally on the femur when more vigorous flexion is attempted. in our study all 19 knees were dislocated.

These cases were operated by me and my assistant orthopaedic surgeon. Anaesthesia was decided by consultant anaesthetist. Preoperative antibiotics were given.

Curtish and Fisher (1969) [1] described a procedure for correction of congenital dislocation of the knee that is recommended for children of 6 to 8 months old.

In our institute for congenital dislocation of knee, capsular release and V-Y quadricepsplasty and $\mathrm{K}$-wiring is done.

Technique: Make a long midline anterior incision starting at the level of the middle third of the femur to the tibial tuberosity.

Expose the anterior thigh muscle and divide the quadriceps mechanism Superior to the patella by long inverted ' $\mathrm{V}$ ' Shaped incision. Adhesion between Vastus, patella and femur are removed. Lateral capsulotomy is done and Preserving hamstrings and popliteal tendon. Knee is flexed for inspection of the menisci and cruciate ligament.

In $60^{\circ}$ flexion of the knee, $\mathrm{K}$-wire is inserted from medial side of proximal tibia and pierces the lateral cortex of lower end femur.

Suture the lengthened quadriceps mechanism in ' $\mathrm{Y}$ ' shape by repair of the vastus medialis to the lengthened rectus femoris. Close the wound after haemostasis then bend $\mathrm{K}$-wire and apply long leg cast with the knee flexed up to $60^{\circ}$.

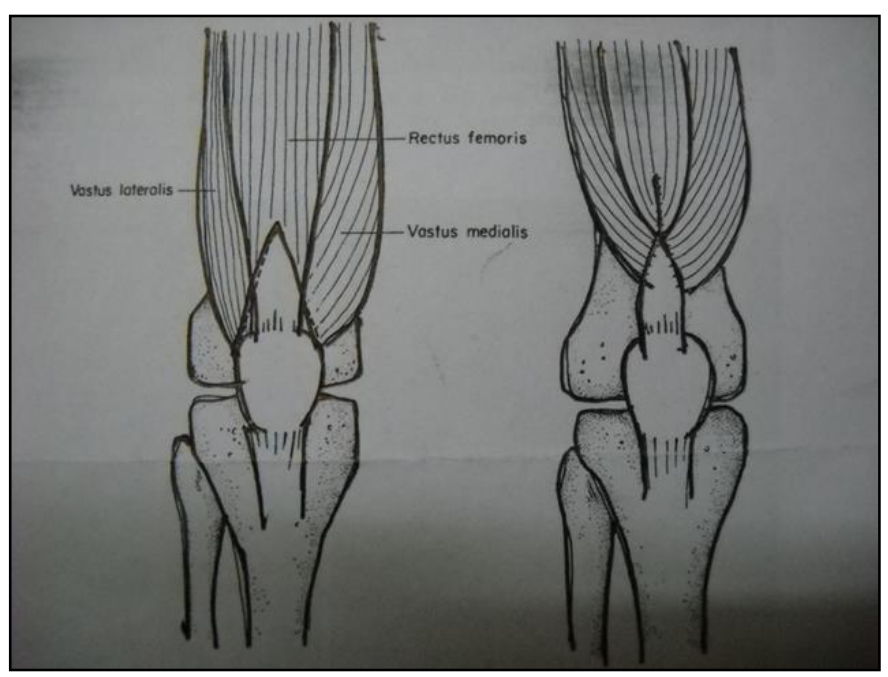

(V-Y quadricepsplasty)
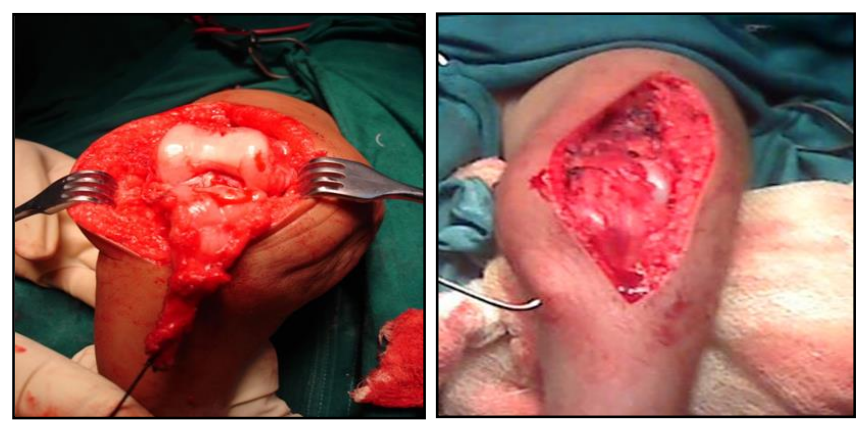

Fig 1: After the inverted V shaped incision of quadriceps mechanism, adhesion removed and lateral capsulotomy done, in $60^{\circ}$ flexion of the knee k-wire inserted then suturing of the lengthened quadriceps mechanism in ' $\mathrm{Y}$ ' shape by repair of the vastus medialis to the lengthened rectus femoris.

After 3 weeks, cast is changed and $\mathrm{K}$-wire is removed and second cast is given with knee in $90^{\circ}$ flexion for 3 wks then AK-BK splint in $90^{\circ}$ flexion is given for $2-3$ months after that night splint is given for 2-3 months and knee exercises are started.

\section{Result}

At final follow up, 15 knees (78.95\%) had good result and 4 knees had fair results $(21.05 \%)$. All 12 patients had ability to walk among wich 8 (66.67) patients were community walker and 4 patients $(33.33 \%)$ were household walker. Only 1 patients had wound healing complication.

Functional outcome assessed by following criteria.

\section{Criteria for result of congenital dislocation of the knee}

\begin{tabular}{|c|c|c|c|}
\hline & Good & Fair & Poor \\
\hline Flexion & $>90^{0}$ & $46^{0}-90^{0}$ & $0^{0}-45^{0}$ \\
\hline Extension lag & $<5^{0}$ & $5^{0}-10^{0}$ & $>10^{0}$ \\
\hline Quadriceps power & $>4^{0}$ & $3^{0}-4^{0}$ & $<3^{0}$ \\
\hline
\end{tabular}

\section{Observation and Analysis}

\section{Sex distribution}

\begin{tabular}{|c|c|c|c|c|c|}
\hline Sex & \multicolumn{2}{|c|}{ Present Series } & \multicolumn{2}{c|}{ Bell, Atkins \& Sharrard Series } & P value \\
\hline & $\begin{array}{c}\text { No. of } \\
\text { Patient }\end{array}$ & $\begin{array}{c}\text { Percentage } \\
(\boldsymbol{\%})\end{array}$ & No. of Patient & Percentage (\%) & \\
\cline { 1 - 5 } Male & 08 & 66.67 & 04 & 80.00 & 0.50 \\
Female & 04 & 33.33 & 01 & 20.00 & \\
Total & 12 & 100.00 & 05 & 100.00 & \\
\hline
\end{tabular}

In our series $\mathrm{M}$ : $\mathrm{F}$ ratio was $2: 1$ with male predominance. In Bell, Atkins \& Sharrard Series M: F ratio was 4:1. Relation of CDK with age was not significant. $(p>0.05)$

\section{Birth Presentation}

\begin{tabular}{|c|c|c|c|c|c|}
\hline $\begin{array}{c}\text { Birth } \\
\text { presentation }\end{array}$ & \multicolumn{2}{|c|}{ Present Series } & \multicolumn{2}{c|}{$\begin{array}{c}\text { Bell, Atkins \& } \\
\text { Sharrard Series }\end{array}$} & P value \\
\hline & $\begin{array}{c}\text { No. of } \\
\text { patient }\end{array}$ & $\begin{array}{c}\text { Percentage } \\
(\%)\end{array}$ & $\begin{array}{c}\text { No. of } \\
\text { patient }\end{array}$ & $\begin{array}{c}\text { Percentage } \\
(\%)\end{array}$ & \multirow{2}{*}{$0.39(p>0.05)$} \\
\hline Vertex & 05 & 41.67 & 01 & 20.00 & \\
\cline { 1 - 5 } Breech & 07 & 58.33 & 04 & 80.00 & \\
\hline Total & 12 & 100.00 & 05 & 100.00 & \\
\hline
\end{tabular}

In our study $58 \%$ had breech presentation which compared to normal average of $3-4 \%$ which was significant. $42 \%$ had vertex presentation. In BELL, ATKINS \& SHARRARD series $80 \%$ had breech presentation and $20 \%$ had vertex presentation. This was statistically not significant. $(p>0.05)$ 


\section{Type of Delivery}

\begin{tabular}{|c|c|c|}
\hline Type of delivery & No. of patient & Percentage (\%) \\
\hline Vaginal & 05 & 41.67 \\
\hline Cesarean section & 07 & 58.33 \\
\hline Total & 12 & 100.00 \\
\hline
\end{tabular}

In our series seven patients had breech presentation with $\mathrm{C} / \mathrm{S}$ $(58.33 \%)$ and 5 patients had vertex presentation with vaginal delivery $(41.67 \%)$.

\section{Previous Treatment}

\begin{tabular}{|c|c|c|}
\hline Previous treatment taken & No. of knee & Percentage (\%) \\
\hline Yes & 08 & 42.10 \\
\hline No & 11 & 57.90 \\
\hline Total & 19 & 100.00 \\
\hline
\end{tabular}

In our series $42 \%$ knee were treated previously at other hospital or institute in form of manipulation or plaster.

\section{Age When Treatment Started}

\begin{tabular}{|c|c|c|}
\hline Age when treatment started by author & No. of Patient & Percentage (\%) \\
\hline 0-1month & 04 & 33.33 \\
\hline 1-6month & 05 & 41.67 \\
\hline 6-12month & 02 & 16.67 \\
\hline >1yr & 01 & 8.33 \\
\hline Total & 12 & 100.00 \\
\hline
\end{tabular}

In our series treatment of $9(75 \%)$ patients started within 6 month of life in which $33.33 \%$ in first month. Late presentation of patient had required higher chances of surgical treatment.

\section{CDK - Idiopathic \& Syndromic}

\begin{tabular}{|c|c|c|}
\hline CDK & No. of patient & Percentage (\%) \\
\hline Idiopathic & 06 & 50.00 \\
\hline Syndromic & 06 & 50.00 \\
\hline Total & 12 & 100.00 \\
\hline
\end{tabular}

In our series $50 \%$ of patients Of CDK were syndromic (associated with AMC). 50\% of patients of CDK were idiopathic

\section{Associated Deformity (DDH \& CTEV) In AMC \& Non} AMC

\begin{tabular}{|c|c|c|c|c|}
\hline \multirow{2}{*}{$\begin{array}{c}\text { CDK associated } \\
\text { with }\end{array}$} & \multicolumn{2}{|c|}{ DDH } & \multicolumn{2}{c|}{ CTEV } \\
\cline { 2 - 5 } & No. of patient & Percentage (\%) & $\begin{array}{c}\text { No. of } \\
\text { patient }\end{array}$ & $\begin{array}{c}\text { Percentage } \\
(\%)\end{array}$ \\
\hline AMC & 04 & 80.00 & 05 & 100.00 \\
\hline NON AMC & 01 & 20.00 & 00 & 00.00 \\
\hline Total & 05 & 100.00 & 05 & 100.00 \\
\hline
\end{tabular}

In our study 4 patients with AMC had DDH and 1 patient not associated with AMC had DDH. 5 patients with AMC had CTEV.

\section{8) Type of Dislocation}

\begin{tabular}{|c|c|c|}
\hline Type & No. of knee & Percentage (\%) \\
\hline Subluxation & -- & -- \\
\hline Recurvatum & -- & -- \\
\hline Dislocation & 19 & 100.00 \\
\hline
\end{tabular}

In our study all 19 knee (12 patients) had ant. dislocation and required surgery.

\section{Complication}

\begin{tabular}{|c|c|c|c|c|c|}
\hline \multirow{3}{*}{ Complication } & \multicolumn{2}{|c|}{ Present Series } & \multicolumn{2}{c|}{$\begin{array}{c}\text { Bell, Atkins \& } \\
\text { Sharrard Series }\end{array}$} & \multirow{2}{*}{ P value } \\
\cline { 2 - 5 } & No. of knee & $\begin{array}{c}\text { Percentage } \\
(\%)\end{array}$ & $\begin{array}{c}\text { No. of } \\
\text { knee }\end{array}$ & $\begin{array}{c}\text { Percentage } \\
(\boldsymbol{\%})\end{array}$ & \\
\hline Wound infection & 00 & 00.00 & 00 & 00.00 & \multirow{2}{*}{0.52} \\
\hline Wound gaping & 01 & 5.26 & 02 & 22.22 & $(p>0.05)$ \\
\hline Others & 00 & 00.00 & 00 & 00.00 & \multicolumn{2}{|c|}{} \\
\hline
\end{tabular}

In our study only 1 knee (case no. 10) had wound gaping. In follow up patient had good result. In BELL, ATKINS \& Sharrard series 2 knees $(22.22 \%)$ had wound gaping. This was statistically not significant. $(p>0.05)$

10) R.O.M

\section{Flexion}

\begin{tabular}{|c|c|c|c|c|c|}
\hline \multirow{2}{*}{ Flexion } & \multicolumn{2}{|c|}{ Present Series } & \multicolumn{2}{c|}{ Bell, Atkins \& Sharrard Series } & P value \\
\cline { 2 - 5 } & $\begin{array}{c}\text { No. of } \\
\text { knee }\end{array}$ & $\begin{array}{c}\text { Percentage } \\
(\boldsymbol{\%})\end{array}$ & $\begin{array}{c}\text { No. of } \\
\text { patient }\end{array}$ & Percentage (\%) & \\
\hline $0^{0}-45^{0}$ & 02 & 10.52 & 01 & 11.11 & \multirow{2}{*}{0.79} \\
\hline $46^{0}-90^{0}$ & 11 & 52.63 & 03 & 33.33 & $(p>0.05)$ \\
\hline$>90^{0}$ & 07 & 36.85 & 05 & 55.56 & \\
\hline Total & 19 & 100.00 & 09 & 100.00 & \\
\hline
\end{tabular}

In our study flexion was in between $0^{0}-120^{\circ}$. Average flexion was $85^{\circ}$. In study of BELL, ATKINS \& SHARRARD flexion was ranging from $0^{0}-150^{\circ}$ and average flexion was $95^{\circ}$. When compared, this was statistically not significant. $(p>0.05)$

\section{Extension Lag}

\begin{tabular}{|c|c|c|c|c|c|}
\hline \multirow{2}{*}{$\begin{array}{c}\text { Extension } \\
\text { lag }\end{array}$} & \multicolumn{2}{|c|}{ Present Series } & \multicolumn{2}{|c|}{ Bell, Atkins \& Sharrard Series } & P value \\
\cline { 2 - 5 } & $\begin{array}{c}\text { No. of } \\
\text { knee }\end{array}$ & $\begin{array}{c}\text { Percentage } \\
(\boldsymbol{\%})\end{array}$ & No. of knee & Percentage (\%) & \multirow{2}{*}{0.68} \\
\hline$<5^{0}$ & 10 & 52.63 & 02 & 22.22 & 33.33 \\
\hline $5^{0}-10^{0}$ & 09 & 47.37 & 03 & 44.45 & \\
\hline$>10^{0}$ & 00 & 00.00 & 04 & 100.00 & \\
\hline Total & 19 & 100.00 & 09 & $0.05)$ \\
\hline
\end{tabular}

In our series extension lag was in between $0^{0}-15^{0}$ and average extension lag was $3^{0}$. In study of BELL, ATKINS \& Sharrard extension lag was in between $0^{0-} 30^{0}$ and average extension lag was $14^{0}$.

\section{Quadriceps Power}

\begin{tabular}{|c|c|c|}
\hline Quadriceps Power & No. of knee & Percentage (\%) \\
\hline 5 & 14 & 73.68 \\
\hline 4 & 05 & 26.32 \\
\hline$\leq 3$ & 00 & 00.00 \\
\hline
\end{tabular}

In our study quadriceps power of all knees were 4 to 5 (100\%) similar to study of Bell, Atkins \& Sharrard.
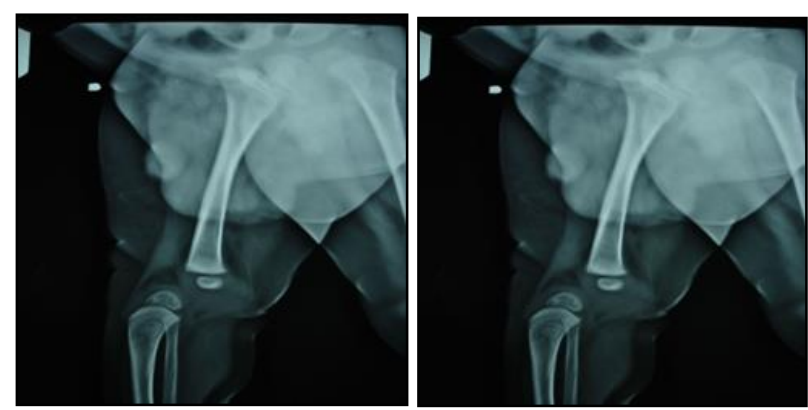

(Pre-operative) 


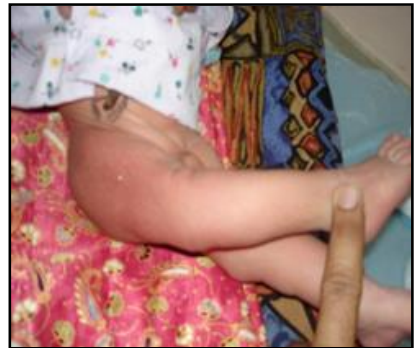

(Pre-operative)

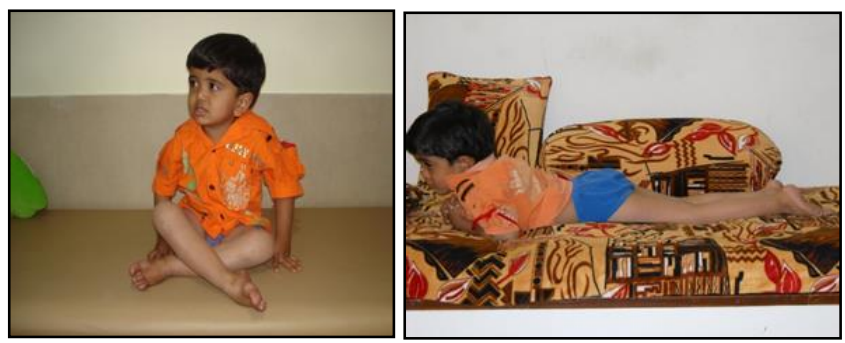

(Final follow up)

\section{Discussion}

We studied the results of operative treatment of CDK in 12 patients (19knees). In our study bilateral dislocation was more common than unilateral with bilateral to unilateral ratio was 1.4:1, left side dislocation was more common than right with left to right ratio was $4: 1$. Male patients were more common than female, with $\mathrm{M}: \mathrm{F}$ ratio was $2: 1$. Sex ratio in CDK was statistically non-significant. In our study $58 \%$ had breech presentation, which compared to normal average of $3-4 \%$ is statistically significant with $\mathrm{P}$ value $=0.02(p<0.05)$. In Bell, Atkins and Sharrard series $80 \%$ had breech presentation; this suggests that breech presentation is probably a contributing factor in CDK. In our study family history of CDK was positive in one patient (Sr.no.10). Relation of CDK with family history was statistically not significant. In our study 5 patients $(41.67 \%)$ had second birth order. Relation of CDK with birth order was statistically not significant. In our study 6 patients were associated with AMC (50\%) and 6 had idiopathic CDK (50\%). Five patients (41.67\%) had DDH among which 4 patients had AMC. In our series $5(41.67 \%)$ patients had CTEV and all these patients were arthrogrypotic. In our series only 1 patient $(5.26 \%)$ had wound gaping. Wound gaping is one of the most common complication associated with quadricepsplasty ${ }^{[6]}$. In Bell, Atkins \& Sharrard series $22.22 \%$ of patients had wound gaping. Our average follow up was 3 year and 8 months. Currently all our patients are under regular follow up. We plan to publish long term follow up study in future. On follow up all 12 patients had ability to walk, among which 8 patients $(66.67 \%)$ were community walker and 4 patients $(33.33 \%)$ were household walker. Seven patients $(58.33 \%)$ had ability to cross leg sitting. Quadriceps powers of all (19) knees were $\geq 4$. Extension lag was seen in 7 patients $(58.33 \%)$. Extension lag was observed in patients who were operated at older age and patients who did not do regular physiotherapy. In our series 15 knees $(78.95 \%)$ had good results and 4 knees $(21.05 \%)$ had fair results. All 6 patients (100.00\%) with idiopathic CDK had good result. Of 6 patients of AMC, 2 patients (33.33\%) had good result and 4 patients $(66.67 \%)$ had fair result. This was due to underlying pathology and associated other limb deformities. This is reported repeatedly in literature ${ }^{[6,14]}$.

\section{Conclusion}

Congenital dislocation of the knee is a rare congenital anomaly. We were fortunate to have significant number of patients with this rare anomaly. In our series $50 \%$ of patients (6) were arthrogrypotic. Higher incidence of breech presentation with $\mathrm{P}$ value $=0.02(p<0.05)$, suggest that breech presentation is probably a contributing factor for congenital dislocation of the knee.

Most of the patients presented at later age requiring higher chances of surgery. If patients are referred at early age, there is possibility of treatment with plaster and decreasing need of surgery.

DDH (41.67\%) and CTEV (41.67\%) were more common in arthrogrypotic patients than idiopathic. Rate of wound complication was low (5.26\%) in our series, this was due to meticulous surgical technique.

All our patients had ability to walk. Patients of idiopathic CDK had good range of movement but arthrogrypotic patients had restricted movement. All Patients of idiopathic CDK had good result. All fair result seen in arthrogrypotic patients due to multiple associate deformities and underlying pathology.

\section{References}

1. Burr Curtish H, Robert Fisher L. Congenital hyperextension with ant. Subluxation of the knee, surgical treatment and long term observation. JBJS. 1969; 51:255-269.

2. Katz MP, Grogono BJS, Soper KC. The aetiology and treatment of congenital dislocation of the knee. JBJS, 1967, 49B.

3. Toshihde Ooishi, Yoichi Sugioka, Shinsuke Matsumoto, Toshi Fujii. Congenital Dislocation of the knee, its pathologic features and treatment. Clinical orthop and related research, 1993.

4. Nirav Shah R, Matthew Dobbs B. A minimally invasive treatment protocol for the congenital Dislocation of the knee. Paediatric Orthopaedic, 2009, 29.

5. Matthew Dobbs B, Stephanie Boehm, Dorothy Grange K, Christina Gurnett A. Studied congenital dislocation in a Patient with Larsen syndrome and a Novel Filamin B mutation. Clinical orthop and related research, 466, 2008.

6. Bell MJ, Atkins RM, Sharrard WJW. Irreducible Congenital dislocation of the knee, aetiology and management. JBJS. 1987; 69(B).

7. Niebaur JJ, King DE. Congenital dislocation of the knee. JBJS (Am.). 1960; 42:207-225.

8. John Anthony Herring: Congenital hyperextension of the knee. Tachdjian's paediatric orthopaedic, 2:919-924.

9. Campbell's operative orthopaedics: Congenital hyperextension of the knee. 2, $11^{\text {th }}$ Edition, 113-115.

10. David Carlson H, John O'Connor. Case report on congenital dislocation of the knee, Am J Roentgenol. 1967; 127:465-468.

11. Ahmadi B, Shahriaree H. CM Silver: Severe Congenital genu recurvatum, case report. JBJS. 1979; 61:622-623.

12. Bose $\mathrm{K}$, Chong KC. The clinical manifestation and pathomechanics of contracture of the extensor mechanism of the knee. JBJS. 1976; 58B:478-484.

13. Austwick DH, Dondy DJ. Early operation for congenital Subluxation of the knee. J Paeditric orthop. 1983; 3:85-7.

14. Ferris B, Aichroth P. The treatment of congenital knee dislocation; A review of the nineteen knees. Clinical Orthop. 1987; 216:135.

15. Roy DR, Crawford AH. Percutaneous quadriceps recession technique for management of congenital 
hyperextension deformities of the knee in neonate. J Paediatric orthop. 1989, 717-719.

16. Haga N, Nakamura S, Sakaguchi R et al. Congenital dislocation of the knee reduced spontaneously or with minimal treatment. J Paediatric orthop. 1997; 17:59-62.

17. Weiss SM, Brooks DB. A Simplified method of splinting for congenital dislocation of the knee, Clin Orthop and related Res. 1977; 216:40-41.

18. Curtis BH, Fisher R. Heritable Congenital tibiofemoral subluxation. Clinical features and surgical treatment. JBJS. 1970; 52A:1104-1114.

19. Eric Johnson, Robert Audell, Willian Oppenheim L. Congenital Dislocation of the knee. J Pediatr Orthop. 1987; 7:194-200.

20. Mohammod Arshad Ikram, Ali Saleh Abdullah, Eman Al Khalfan. Congenital genu recurvatum with dislocation of the knees: A case report. Kuwait Medical Journal. 2004; 36(3):203-205.

21. Sijmons Van Essen, Visser Iprenburg, Nelck VosBender, De Jong. Congenital knee dislocation in a 49 XXXXY boy. J Med Genet. 1995; 32:309-311. 